\title{
Selection of common bean land cultivars based on agronomic performance, cooking time, and mineral concentration
}

\section{Seleção de cultivares crioulas de feijão com base no desempenho agronômico, cozimento e concentração de minerais}

\author{
Narielen Moreira de Morais ${ }^{1}$; Nerinéia Dalfollo Ribeiro ${ }^{2 *}$; Lindolfo Storck ${ }^{3}$; \\ Paulo Rogério Franco dos Santos ${ }^{4}$; Micheli Thaise Della Flora Possobom ${ }^{1}$
}

\begin{abstract}
The potential use of common bean land cultivars with respect to their agronomic performance, cooking time and nutritional quality has scarcely been evaluated in breeding programs. The objective of the present study was to evaluate 19 common bean land cultivars for their agronomic traits, cooking time, and mineral concentration in grains to identify cultivars for potential use by a higher number of farmers or even breeding programs. Two field experiments were conducted in Alegrete and Santa Maria, Rio Grande do Sul (RS), Brazil, in the 2012/2013 season. The experimental design consisted of randomized blocks with three replications. A total of 23 cultivars were evaluated; 19 land cultivars were obtained from smallholder farmers from RS, and there were four control cultivars (Carioca, Pérola, BRS Valente, and Guapo Brilhante). The traits evaluated included the cycle, insertion of the first pod, grain yield, cooking time, and concentrations of calcium, iron, zinc, and copper in the grains. The data were subjected to joint variance analysis, Pearson correlation analysis, and the $\bar{Z}$ index. The common bean cultivars showed differences in the cycle, insertion of the first pod, grain yield, cooking time, calcium, iron, zinc, and copper concentrations in grains, and the $\bar{Z}$ index. The cultivars Preto Miúdo and Cavalo Rajado had a high grain yield, i.e., greater than $2,900 \mathrm{~kg} \mathrm{ha}^{-1}$. The land cultivars were classified as having early and intermediate cycles, and all had cooking times less than $30 \mathrm{~min}$. Palha Roxa, Carioca Vermelho, and Perdiz had high concentrations of calcium, iron, zinc, and copper in the grains, an intermediate cycle, and low grain yield. Positive correlations of moderate magnitude were observed between the calcium and iron $(\mathrm{r}=0.597)$, iron and zinc $(\mathrm{r}=0.570)$, and zinc and copper $(\mathrm{r}=0.548)$ concentrations. Indirect selection for high iron or zinc concentrations in grains will be effective for obtaining common bean cultivars with a higher nutritional quality. A cross between Carioca Santa Maria and Guapo Brilhante cultivar is recommended to obtain segregants with high agronomic performance, fast cooking, and high minerals concentration in the grains.
\end{abstract}

Key words: $\bar{Z}$ index. Genotype $\mathrm{x}$ environment interaction. Phaseolus vulgaris L. Genetic variability.

\section{Resumo}

O potencial de uso das cultivares crioulas de feijão quanto ao desempenho agronômico e a qualidade de cozimento e nutricional foi pouco avaliado pelos programas de melhoramento. O objetivo deste trabalho foi avaliar 19 cultivares crioulas de feijão quanto aos caracteres agronômicos, tempo de

${ }^{1}$ Eng $^{\text {os }}$ Agros $^{\text {, }}$ Discentes do Curso de Mestrado em Agronomia, Universidade Federal de Santa Maria, UFSM, Cidade Universitária, Santa Maria, RS, Brasil. E-mail: narielenmorais@hotmail.com; michepossobom@yahoo.com.br

2 Eng $^{\circ}$ Agr $^{\circ}$, Prof. Associado IV, UFSM, Departamento de Fitotecnia, Cidade Universitária, Cidade Universitária, Santa Maria, RS, Brasil. E-mail: nerineia@hotmail.com

${ }^{3}$ Eng $^{\circ}$ Agr $^{\circ}$, Prof. Dr., Universidade Tecnológica Federal do Paraná, UTFPR, Gerência de Pesquisa e Pós-Graduação, Pato Branco, PR, Brasil. E-mail: lindolfostorck@gmail.com

${ }^{4}$ Discente do Curso de Graduação em Tecnologia em Produção de Grãos, Instituto Federal Farroupilha, IFF, Alegrete, RS, Brasil. E-mail: paulosantos_ps@hotmail.com

* Author for correspondence 
cozimento e concentração de minerais nos grãos, de forma a identificar cultivares com potencial de uso por mais agricultores e mesmo em programas de melhoramento. Dois experimentos de campo foram conduzidos em Alegrete e em Santa Maria, RS, Brasil, no ano agrícola 2012/2013. O delineamento experimental foi em blocos ao acaso com três repetições, e 23 cultivares foram avaliadas, 19 cultivares crioulas obtidas com agricultores familiares do RS e quatro testemunhas (Carioca, Pérola, BRS Valente e Guapo Brilhante). Os caracteres avaliados foram ciclo, altura de inserção da primeira vagem, produtividade de grãos, tempo de cozimento e concentração de cálcio, ferro, zinco e cobre nos grãos. Os dados foram submetidos a análise de variância conjunta, a análise de correlação de Pearson e ao índice $\bar{Z}$. As cultivares de feijão apresentaram diferenças para ciclo, altura de inserção da primeira vagem, produtividade de grãos, tempo de cozimento, concentração de cálcio, ferro, zinco e cobre nos grãos e índice $\bar{Z}$. As cultivares Preto Miúdo e Cavalo Rajado apresentaram alta produtividade de grãos, superior a $2.900 \mathrm{~kg} \mathrm{ha}^{-1}$. As cultivares crioulas foram classificadas em ciclo precoce e intermediário, e todas foram de cozimento inferior a 30 minutos. Palha Roxa, Carioca Vermelho e Perdiz apresentaram alta concentração de cálcio, ferro, zinco e cobre nos grãos, ciclo intermediário e baixa produtividade de grãos. Estimativas de correlação positiva e de moderada magnitude foram observadas entre a concentração de cálcio e ferro $(\mathrm{r}=0,597)$, ferro e zinco $(\mathrm{r}=0,570)$ e zinco e cobre $(\mathrm{r}=0,548)$. A seleção indireta para alta concentração de ferro ou de zinco nos grãos será eficiente para a obtenção de cultivares de feijão de maior qualidade nutricional. O cruzamento entre as cultivares Carioca Santa Maria e Guapo Brilhante é recomendado para a obtenção de segregantes com alto desempenho agronômico, cozimento rápido e alta concentração de minerais nos grãos.

Palavras-chave: Índice $\bar{Z}$. Interação genótipo x ambiente. Phaseolus vulgaris L. Variabilidade genética.

\section{Introduction}

Common bean (Phaseolus vulgaris L.) cultivation in Brazil is characterized by a low use of seed during planting. In the 2013/2014 season, the rate of common bean seed use was of $19 \%$ nationwide and only 3\% in the Rio Grande do Sul state (ABRASEM, 2015). Thus, there is predominant use of the grains that are conserved and multiplied by farmers for the bean production.

As the common bean plant is autogamous, the genetic variability observed within a cultivar can be due to mutation or cross-fertilization that is up to $8 \%$ natural crossing according by Frankel and Galun (1977), mechanical mixtures, or the presence of different genotypes or atypical plants that were not adequately eliminated during the production of initial batches of genetic seed. Over the years, new cultivars with varied colours and size grains and with different agronomic traits have appeared as a result of natural or human selection. This genetic resource, maintained by smallholder farmers, has been termed common bean land cultivars and is an important source of genetic diversity for breeding programs (ELIAS et al., 2007).
Some common bean land cultivars possess agronomic traits that would be desirable for incorporation into current cultivars, such as lower plant height, erect plant architecture and high grain yield (ELIAS et al., 2007). The following traits have been considered: cycle, grain yield, grain yield components, occurrence of disease, and other morphological traits (BONETT et al., 2006; COELHO et al., 2010; ELIAS et al., 2007; RIBEIRO et al., 2008a; ZILIO et al., 2011, 2013). Nutritional traits, such as the protein percentage (ELIAS et al., 2007; PEREIRA et al., 2011), dietary fiber (RIBEIRO et al., 2008a), and mineral concentration (PEREIRA et al., 2011), have recently been considered in the evaluation of common bean land cultivars. However, studies evaluating the cooking time of common bean land cultivars have not been found in the literature.

The cooking time and nutritional quality of beans grains are as important as the high agronomic performance of common bean cultivars. Breeding programs seek to aggregate technological traits in new cultivars, thus providing market advantages for common bean producers. Studies with common bean land cultivars aimed at combined selection 
for agronomic traits, fast cooking, and high mineral concentration in the grains are rare. Thus, the objective of the present study was to evaluate 19 common bean land cultivars for their agronomic traits, cooking time, and minerals concentration in the grains to identify cultivars with potential use by a higher number of farmers or even breeding programs.

\section{Materials and Methods}

The experiments were performed in the 2012/2013 season on the Farroupilha Federal
Institute, in Alegrete, Rio Grande do Sul state (RS), Brazil (latitude 29 $43^{\prime} \mathrm{S}$, longitude $55^{\circ} 31^{\prime} \mathrm{W}$ and altitude $107 \mathrm{~m}$ ), and on the Federal University of Santa Maria, in the Department of Crop Science, in Santa Maria, RS (latitude $29^{\circ} 42^{\prime} \mathrm{S}$, longitude $53^{\circ} 49^{\prime} \mathrm{W}$ and altitude $\left.95 \mathrm{~m}\right)$. The predominant climate of both locations is humid subtropical Cfa, with rain that is well distributed over the year. However, the two growing locations have different average minimum and maximum temperatures as well as amount and distribution of precipitation (Table 1).

Table 1. Meteorological data collected in the $8^{\text {th }}$ Meteorological District of the Meteorological Station of Alegrete, located at the Farroupilha Federal Institute, Alegrete Campus (latitude $29^{\circ} 71^{\prime} \mathrm{S}$, longitude $55^{\circ} 52^{\prime} \mathrm{W}$, and $121 \mathrm{~m}$ altitude) and at the Meteorological Station of Santa Maria, located at the Federal University of Santa Maria, University City (latitude $29^{\circ} 42^{\prime} \mathrm{S}$, longitude 53 $49^{\prime} \mathrm{W}$, and $95 \mathrm{~m}$ altitude), in the 2012/2013 season in the Rio Grande do Sul (RS) state, Brazil.

\begin{tabular}{lcccccccc}
\hline & \multicolumn{4}{c}{----Alegrete---- } & \multicolumn{4}{c}{----Santa Maria---- } \\
\cline { 2 - 8 } & Nov & Dec & Jan & Feb & Nov & Dec & Jan & Feb \\
\hline Minimum temperature $\left({ }^{\circ} \mathrm{C}\right)$ & 22.8 & 23.0 & 22.6 & 22.9 & 22.0 & 23.3 & 22.2 & 22.8 \\
Maximum temperature $\left({ }^{\circ} \mathrm{C}\right)$ & 24.4 & 24.2 & 23.9 & 24.1 & 23.4 & 24.5 & 23.7 & 24.2 \\
Average temperature $\left({ }^{\circ} \mathrm{C}\right)$ & 23.6 & 23.6 & 23.2 & 23.5 & 22.7 & 23.9 & 22.9 & 23.5 \\
Rainfall $(\mathrm{mm})$ & 16.5 & 373.4 & 124.0 & 213.8 & 78.8 & 313.4 & 151.6 & 102.2 \\
\hline
\end{tabular}

In Alegrete, the bean plants were grown in a sandy Dystrophic Red Argisol that was prepared with minimum tillage. In Santa Maria, the experiment was set up in soil classified as a typicall alitic Argisol, Hapludalf that was prepared conventionally. Fertility correction and fertilization were performed according to the interpretation of soil chemical analysis at each growing site. In Alegrete, $230 \mathrm{~kg}$ $\mathrm{ha}^{-1}$ of N-P-K (5-20-20 formulation) was applied at furrow sowing, and $20 \mathrm{~kg} \mathrm{ha}^{-1}$ of nitrogen, in urea form, was split in the first trifoliate leaf growth stage (V3). In Santa Maria, $195 \mathrm{~kg} \mathrm{ha}^{-1}$ of a 5-2020 formulation was applied at the furrow sowing, and $20 \mathrm{~kg} \mathrm{ha}^{-1}$ of urea was added in the V3 stage. The experiments were conducted under natural "rainfed" conditions, without irrigation.

The experimental design used was randomized blocks with three replications. Each plot consisted of two rows $4.0 \mathrm{~m}$ in length, with $0.5 \mathrm{~m}$ spacing between rows and a useful area of $4.0 \mathrm{~m}^{2}$, without lateral and end borders, as the harvest occurred across the total area of the plot. Nineteen common bean land cultivars obtained from farmers at markets in different municipalities of RS and four control cultivars were evaluated, i.e., a total of 23 treatments (Table 2). Seeding was performed on November 2, 2012, in Alegrete, and on November 7 , 2012, in Santa Maria, that is, within the $1^{\text {st }}$ growing season or "rainy season" in the Rio Grande do Sul state (CTSBF, 2012). Weed control was carried out by hoeing. For insect control, Thiamethoxam + Lambda-cyhalothrin was applied at a dose of $125 \mathrm{~mL}$ $\mathrm{ha}^{-1}$ at the start of insect infestation, as recommended by the Ministry of Agriculture, Livestock, and Food Supply (MAPA, 2015). Disease control was not performed in any of the experiments. 
Table 2. Common name, grain type (type), seed coat colour (background colour), coloration of stripes or specks of grains (secondary colour), growth habit $(\mathrm{GH})$, seeding density ( $\mathrm{SD}$, number of seeds $\mathrm{m}^{-1}$ line), and plant population (population, number of plants ha ${ }^{-1}$ ) of land and control common bean cultivars evaluated in Alegrete and Santa Maria in the $2012 / 2013$ season.

\begin{tabular}{|c|c|c|c|c|c|c|}
\hline Cultivars & Type & Background colour & Secondary colour & $\mathrm{GH}^{*}$ & SD & Population \\
\hline \multicolumn{7}{|c|}{ 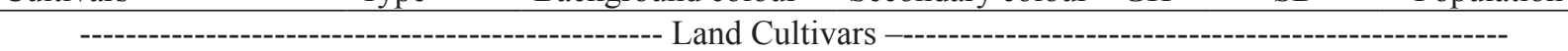 } \\
\hline Carioca Santa Maria & Carioca & Brown & Dark Brown & III & 13 & 220,000 \\
\hline Azulão & Black & Black & Absent & II & 16 & 260,000 \\
\hline Banana & Black & Black & Absent & I & 18 & 300,000 \\
\hline Guabiju & Black & Black & Absent & III & 13 & 220,000 \\
\hline Palha Roxa & Black & Black & Absent & II & 16 & 260,000 \\
\hline Preto Miúdo & Black & Black & Absent & III & 13 & 220,000 \\
\hline Amendoim & Red & Red & Absent & II & 16 & 260,000 \\
\hline Amendoim Rio Pardo & Red & Red & Absent & II & 16 & 260,000 \\
\hline Cavalo & Cranberry & Beige & Black & I & 18 & 300,000 \\
\hline Cavalo Rajado & Cranberry & Beige & Black & I & 18 & 300,000 \\
\hline Cavalo Rio Pardo & Cranberry & Beige & Gray-Brown & I & 18 & 300,000 \\
\hline Rajado Vermelho & Cranberry & Red & Pink & I & 18 & 300,000 \\
\hline Grosso Santa Maria & Moorish & Purple & Black & II & 16 & 260,000 \\
\hline Grosso Ibarama & Moorish & Purple & Black & II & 16 & 260,000 \\
\hline Mourinho & Moorish & Grey & Black & II & 16 & 260,000 \\
\hline Mourinho Marrom & Moorish & Brown & Light Brown & III & 13 & 220,000 \\
\hline Carioca Vermelho & $* * N D G$ & Red & Black & II & 16 & 260,000 \\
\hline Perdiz & $* * \mathrm{NDG}$ & Brown & Grey & II & 16 & 260,000 \\
\hline Tubiano & $* * \mathrm{NDG}$ & Red & White & $\mathrm{I}$ & 18 & 300,000 \\
\hline \multicolumn{7}{|c|}{---------------------------------------------------- Control Cultivars ----------------------------------------------------- } \\
\hline Carioca & Carioca & Beige & Brown & III & 13 & 220,000 \\
\hline Pérola & Carioca & Beige & Brown & III & 13 & 220,000 \\
\hline BRS Valente & Black & Black & Absent & II & 16 & 260,000 \\
\hline Guapo Brilhante & Black & Black & Absent & II & 16 & 260,000 \\
\hline
\end{tabular}

* GH: growth habit: I: determinate, II: indeterminate with short guides, III: indeterminate with long guides.

$* * \mathrm{NDG}=$ no defined group.

The cycle was evaluated for the period between plant emergence and maturation, considering half plus one of the plants in the experimental unit reached stage $\mathrm{R} 9$ (maturation), i.e. when the pods lost their pigmentation and began to dry. Next, 10 plants were randomly harvested to determine the insertion of the first pod. Here, the distance between the ground level and the insertion of the first pod was measured in $\mathrm{cm}$. The remaining plants in the experimental unit were harvested manually to determine the grain yield, which was calculated by extrapolating of the weight of the product obtained in each experimental unit per hectare at $13 \%$ average moisture.
The evaluation of the cooking time of the grains was conducted in a Mattson's cooking of 25 pegs. First, 25 grains were soaked in $50 \mathrm{~mL}$ of distilled water in $200-\mathrm{mL}$ plastic cups for eight hours at room temperature $\left(20 \pm 2^{\circ} \mathrm{C}\right)$. Next, the water was discarded, and each grain was positioned under a peg of the cooker. The device was placed in a 7-L pressure cooker containing $3 \mathrm{~L}$ of boiling distilled water. The cooker was kept open and over medium heat, and when a grain was cooked, the peg would fall and penetrate the soft grain. The average fall time of the first 13 pegs was considered the average cooking time of each sample (RIBEIRO et al., 2007). 
The determination of the mineral concentration in the grains was conducted on two replications for each study location. Bean samples ( $5 \mathrm{~g}$ ) were ground in an analytical micro-mill to produce particles smaller than $1 \mathrm{~mm}$. A sample of $0.5 \mathrm{~g}$ of raw bean flour was used for nitric-perchloric digestion $\left(\mathrm{HNO}_{3}\right.$ $+\mathrm{HClO}_{4}$ ), according to the methodology described by Miyazawa et al. (1999). The calcium, iron, zinc, and copper concentrations were determined in an atomic absorption spectrophotometer.

The data were subjected to individual and joint variance analysis. Homogeneity of residual variance was assessed using the Hartley maximum $\mathrm{F}$ test. The $\mathrm{F}$ test was used to hypotheses test of the principal effects (cultivar and location) and the cultivar $x$ location interaction of the fixed effect. The means were compared using the test of Scott and Knott (1974) at 5\% probability. Pearson correlation coefficients were estimated using a phenotypic correlation matrix; the significance of the coefficients was calculated using Student's $t$ test.

The data obtained from each plot were standardized within each block, allowing them to be directly comparable. Using this procedure, all blocks had the same $\bar{Z}$ index (=zero), and in turn, the average of each location was also equal to zero, which eliminated the effect of location and block/location while maintaining the other sources of variation. The selection index ( $\bar{Z}$ index) was estimated as described in Mendes et al. (2009). As the minerals were determined using different numbers of replications, the average of the $\bar{Z}$ index was considered in the traits present in J replications, adding a constant equal to three to avoid negative values. Using the same procedure adopted by Mendes et al. (2009), charts were developed to assess the contribution of each trait standardized in the $\bar{Z}$ index value, allowing the visual identification of cultivars with the highest $\bar{Z}$ index averages for all traits. The analyses were performed using Microsoft Office Excel spreadsheets and the Genes software (CRUZ, 2013).

\section{Results and Discussion}

The variance of the experimental error was homogenous ( $p>0.05$ ) for both growing locations, enabling the joint variance analysis for all traits evaluated. In the joint variance analysis, a significant cultivar $\mathrm{x}$ location interaction $(\mathrm{p}<0.05)$ was observed for cycle, insertion of the first pod, grain yield, and cooking time (Table 3), indicating that the common bean cultivars responded differently to environmental variations. A significant cultivar $\mathrm{x}$ environment interaction has been previously described for the cycle (RIBEIRO et al., 2008a), insertion of the first pod (COELHO et al., 2010), and grain yield (COELHO et al., 2010; RIBEIRO et al., 2008a; ZILIO et al., 2011) in experiments evaluating the performance of common bean land cultivars. In the present study, the cultivar $\mathrm{x}$ location interaction was not significant for the calcium, iron, zinc, and copper concentrations, enabling the selection of superior cultivars for these minerals for the two growing environments.

A significant cultivar effect $(p<0.05)$ was observed for all traits evaluated and consequently for the $\bar{Z}$ index, which is a linear function of the traits. Similarly, Mesquita et al. (2007) and Silva et al. (2012), who evaluated common bean lines and cultivars, found differences in the calcium, iron, zinc, and copper concentrations in grains of the germplasm studied. The common bean cultivars in the current study exhibited significant differences for all traits evaluated, enabling the selection of superior land cultivars for agronomic traits, fast cooking, and high minerals concentration in grains. 
Table 3. Joint variance analysis of land and control common bean cultivars for the traits number of days from emergence to maturation (cycle, days), insertion of the first pod (first pod, $\mathrm{cm}$ ), grain yield (yield, $\mathrm{kg} \mathrm{ha}^{-1}$ ), cooking time (cooking, seconds), concentrations of calcium ( $\mathrm{g} \mathrm{kg}^{-1}$ dry matter $\left.-\mathrm{DM}\right)$, iron, zinc, and copper $\left(\mathrm{mg} \mathrm{kg}^{-1} \mathrm{DM}\right)$ in grains, and the $\bar{Z}$ index, evaluated in Alegrete and Santa Maria, RS, in the 2012/2013 season.

\begin{tabular}{|c|c|c|c|c|c|c|c|c|c|c|c|c|}
\hline \multirow{2}{*}{$\begin{array}{c}\text { Source } \\
\text { of } \\
\text { variation }\end{array}$} & \multicolumn{5}{|c|}{ Mean squares* } & \multicolumn{7}{|c|}{ Mean squares* } \\
\hline & DF & Cycle & First pod & Yield & Cooking & DF & Calcium & Iron & Zinc & Copper & Index & $\bar{Z}$ \\
\hline $\begin{array}{l}\text { Cultivar } \\
\text { (C) }\end{array}$ & 22 & $454.24 *$ & $246.01 *$ & $3408451.90 *$ & $101246.44 *$ & 22 & $1.769 *$ & $153.16 *$ & $123.51 *$ & $6.255 *$ & 0.716 & $*$ \\
\hline $\begin{array}{l}\text { Location } \\
\text { (L) }\end{array}$ & 1 & $505.04 *$ & $378.98 *$ & 3850352.18 * & 9318.52 & 1 & 0.133 & $849.32 *$ & $78.16 *$ & 0.546 & - & \\
\hline $\mathrm{CxL}$ & 22 & $29.75 *$ & $40.46 *$ & 302389.60 * & $34344.37 *$ & 22 & 0.189 & 22.59 & 19.15 & 1.352 & 0.121 & \\
\hline $\begin{array}{l}\text { Block/ } \\
\text { Location }\end{array}$ & 4 & 10.33 & 16.80 & 600691.63 & 11934.58 & 2 & 0.128 & 248.00 & 54.45 & 5.037 & - & \\
\hline Error & 88 & 18.34 & 21.63 & 158962.87 & 15305.67 & 44 & 0.123 & 23.57 & 18.93 & 1.128 & 0.079 & \\
\hline Mean & & 79.91 & 29.94 & 1778.94 & 1452.75 & & 1.94 & 39.59 & 48.69 & 10.687 & 2.97 & \\
\hline $\mathrm{CV}(\%)$ & & 5.36 & 15.53 & 22.41 & 8.51 & & 18.11 & 12.26 & 8.94 & 9.93 & - & \\
\hline
\end{tabular}

* Significant at $5 \%$ according to the $\mathrm{F}$ test.

The common bean cultivars had cycle ranging from 60 (Cavalo Rio Pardo, Santa Maria) to 91 days (Amendoim, Alegrete) (Table 4). In the crop grown in Alegrete, the land cultivars Azulão, Guabiju, Cavalo, Cavalo Rajado, Cavalo Rio Pardo, and Grosso Santa Maria had cycle that were similar or earlier than those of the control cultivars Pérola and Guapo Brilhante. In Santa Maria, the land cultivars Azulão, Guabiju, Cavalo, Cavalo Rajado, Cavalo Rio Pardo, and Grosso Santa Maria and the control cultivar Guapo Brilhante had early cycle. Previous studies have shown that the cycle of common bean land cultivars changes depending on year (RIBEIRO et al., 2008a) and growing location (ZILIO et al., 2013). Thus, identification of common bean land cultivars with early cycle, defined by Zimmermann and Teixeira (1996) as those cultivars with approximately 70 days from emergence to maturation, independent of growing environment, is of great importance to breeding programs. Based on the averages obtained by cycle in Alegrete and Santa Maria, in the rainy season, it was possible to select six common bean land cultivars with early cycle: Azulão, Guabiju, Cavalo, Cavalo Rajado, Cavalo
Rio Pardo, and Grosso Santa Maria (Table 4). The others land cultivars evaluated had intermediate cycle.

The land cultivars Carioca Santa Maria, Palha Roxa, Preto Miúdo, Amendoim Rio Pardo, Rajado Vermelho, Grosso Ibarama, Mourinho, Mourinho Marrom, Carioca Vermelho, and Perdiz had a higher insertion of the first pod in Alegrete (29.22 to $36.43 \mathrm{~cm}$ ), which did not differ significantly from the control cultivars Carioca, Pérola and BRS Valente (Table 4). In Santa Maria, three land cultivars (Amendoim, Mourinho, and Carioca Vermelho) surpassed the four control cultivars with respect to the insertion of the first pod. Similarly, Zilio et al. (2013) observed that the insertion of the first pod, which was evaluated for 22 common bean land cultivars, varied by growing location, and the ranking of the cultivars changed when they were evaluated in another environment in the Santa Catarina state. The cultivars Mourinho and Carioca Vermelho had a higher insertion of the first pod in both growing locations and are therefore promising for breeding programs. 
Table 4. Averages* of land and control bean cultivars for number of days from emergence to maturation (cycle), insertion of the first pod (first pod), grain yield (yield), and cooking time (cooking), evaluated in Alegrete (AL) and Santa Maria (SM), RS, in the 2012/2013 season.

\begin{tabular}{|c|c|c|c|c|c|c|c|c|c|c|c|}
\hline \multirow{3}{*}{ Cultivar } & \multicolumn{2}{|c|}{ Cycle } & \multicolumn{2}{|c|}{ First pod } & \multicolumn{3}{|c|}{ Yield } & \multicolumn{4}{|c|}{ Cooking } \\
\hline & $\mathrm{AL}$ & SM & $\mathrm{AL}$ & SM & $\mathrm{AL}$ & & SM & $\mathrm{AL}$ & & SM & \\
\hline & \multicolumn{2}{|c|}{ days } & \multicolumn{2}{|c|}{$\mathrm{cm}$} & \multicolumn{3}{|c|}{$\mathrm{Kg} \mathrm{ha}^{-1}$} & \multicolumn{4}{|c|}{ min:sec } \\
\hline Carioca Santa Maria & $87.33 \mathrm{a}$ & $82.33 \mathrm{a}$ & $29.77 \mathrm{a}$ & $36.43 \mathrm{~b}$ & 1,587 & $\mathrm{c}$ & $1,563 \mathrm{~d}$ & $25: 47$ & $\mathrm{a}$ & $29: 53$ & $\mathrm{a}$ \\
\hline Azulão & $70.33 \mathrm{~b}$ & $62.33 \mathrm{c}$ & $24.07 \mathrm{~b}$ & $23.08 \mathrm{c}$ & 1,458 & $\mathrm{c}$ & $965 \mathrm{e}$ & $24: 35$ & $\mathrm{a}$ & $24: 55$ & b \\
\hline Banana & $89.33 \mathrm{a}$ & $84.67 \mathrm{a}$ & $23.23 \mathrm{~b}$ & $22.79 \mathrm{c}$ & 438 & $\mathrm{~d}$ & $606 \mathrm{e}$ & $18: 23$ & $\mathrm{~b}$ & 20:08 & $\mathrm{c}$ \\
\hline Guabiju & $68.67 \mathrm{c}$ & $66.67 \mathrm{~b}$ & $27.18 \mathrm{~b}$ & $26.30 \mathrm{c}$ & 1,889 & $\mathrm{c}$ & $2,428 \mathrm{c}$ & $25: 39$ & $\mathrm{a}$ & $26: 07$ & b \\
\hline Palha Roxa & $87.33 \mathrm{a}$ & $78.33 \mathrm{a}$ & $29.22 \mathrm{a}$ & $34.16 \mathrm{~b}$ & 1,293 & $\mathrm{c}$ & $2,217 \mathrm{c}$ & $22: 19$ & $\mathrm{~b}$ & $26: 19$ & $\mathrm{~b}$ \\
\hline Preto Miúdo & $86.33 \mathrm{a}$ & $84.67 \mathrm{a}$ & $35.58 \mathrm{a}$ & $38.07 \mathrm{~b}$ & 3,326 & $\mathrm{a}$ & 3,746 a & $26: 58$ & $\mathrm{a}$ & $25: 38$ & 0 \\
\hline Amendoim & $91.00 \mathrm{a}$ & $83.67 \mathrm{a}$ & $25.65 \mathrm{~b}$ & $43.77 \mathrm{a}$ & 782 & d & 967 e & $27: 07$ & $\mathrm{a}$ & $22: 31$ & $c$ \\
\hline Amendoim Rio Pardo & $88.00 \mathrm{a}$ & $78.33 \mathrm{a}$ & $33.61 \mathrm{a}$ & $35.50 \mathrm{~b}$ & 811 & d & $1,143 \mathrm{~d}$ & $24: 59$ & $\mathrm{a}$ & $24: 44$ & b \\
\hline Cavalo & $68.00 \mathrm{c}$ & $61.33 \mathrm{c}$ & $16.85 \mathrm{c}$ & $20.62 \mathrm{c}$ & 1,824 & $\mathrm{c}$ & $1,982 \mathrm{c}$ & $22: 05$ & $\mathrm{~b}$ & $21: 34$ & $\mathrm{c}$ \\
\hline Cavalo Rajado & $64.33 \mathrm{c}$ & $60.33 \mathrm{c}$ & $18.36 \mathrm{c}$ & $20.64 \mathrm{c}$ & 2,927 & $\mathrm{a}$ & $3,251 \mathrm{~b}$ & $20: 26$ & $\mathrm{~b}$ & $24: 20$ & $\mathrm{~b}$ \\
\hline Cavalo Rio Pardo & $73.33 \mathrm{~b}$ & $60.00 \mathrm{c}$ & $16.70 \mathrm{c}$ & $21.37 \mathrm{c}$ & 1,329 & $\mathrm{c}$ & $1,811 \mathrm{c}$ & $24: 17$ & $\mathrm{a}$ & $21: 11$ & $\mathrm{c}$ \\
\hline Rajado Vermelho & $89.67 \mathrm{a}$ & $84.67 \mathrm{a}$ & $29.94 \mathrm{a}$ & $28.02 \mathrm{c}$ & 1,432 & $\mathrm{c}$ & $694 \mathrm{e}$ & $23: 38$ & $\mathrm{a}$ & $25: 54$ & $\mathrm{~b}$ \\
\hline Grosso Santa Maria & $73.67 \mathrm{~b}$ & $67.33 \mathrm{~b}$ & $24.01 \mathrm{~b}$ & $27.36 \mathrm{c}$ & 1,597 & $\mathrm{c}$ & $2,193 \mathrm{c}$ & $24: 19$ & $\mathrm{a}$ & $27: 52$ & a \\
\hline Grosso Ibarama & $85.33 \mathrm{a}$ & $84.00 \mathrm{a}$ & $34.56 \mathrm{a}$ & $39.01 \mathrm{~b}$ & 1,443 & $\mathrm{c}$ & $2,211 \mathrm{c}$ & $27: 30$ & $\mathrm{a}$ & 28:01 & a \\
\hline Mourinho & $85.67 \mathrm{a}$ & $86.33 \mathrm{a}$ & $30.55 \mathrm{a}$ & $42.49 \mathrm{a}$ & 1,728 & $\mathrm{c}$ & $2,560 \mathrm{c}$ & $27: 28$ & $\mathrm{a}$ & $23: 53$ & $\mathrm{c}$ \\
\hline Mourinho N & $86.00 \mathrm{a}$ & $85.00 \mathrm{a}$ & $31.71 \mathrm{a}$ & $33.56 \mathrm{~b}$ & 1,841 & $\mathrm{c}$ & $1,817 \mathrm{c}$ & $25: 38$ & $\mathrm{a}$ & $24: 44$ & b \\
\hline Carioca Vermelho & $84.67 \mathrm{a}$ & $85.33 \mathrm{a}$ & $36.43 \mathrm{a}$ & $46.38 \mathrm{a}$ & 1,272 & $\mathrm{c}$ & $1,434 \mathrm{~d}$ & $21: 37$ & $\mathrm{~b}$ & $21: 28$ & $\mathrm{c}$ \\
\hline Perdiz & $84.00 \mathrm{a}$ & $84.67 \mathrm{a}$ & $30.99 \mathrm{a}$ & $36.67 \mathrm{~b}$ & 1,188 & $\mathrm{c}$ & $2,521 \mathrm{c}$ & $19: 58$ & $\mathrm{~b}$ & $22: 55$ & $\mathrm{c}$ \\
\hline Tubiano & $86.67 \mathrm{a}$ & $84.33 \mathrm{a}$ & $25.97 \mathrm{~b}$ & $21.91 \mathrm{c}$ & 463 & d & $482 \mathrm{e}$ & $23: 52$ & $\mathrm{a}$ & $24: 14$ & b \\
\hline Carioca $^{1}$ & $87.67 \mathrm{a}$ & $84.33 \mathrm{a}$ & $38.57 \mathrm{a}$ & $32.28 \mathrm{~b}$ & 2,451 & $\mathrm{~b}$ & $2,545 \mathrm{c}$ & $25: 19$ & $\mathrm{a}$ & $23: 04$ & $\mathrm{c}$ \\
\hline Pérola $^{1}$ & $77.67 \mathrm{~b}$ & $86.00 \mathrm{a}$ & $31.66 \mathrm{a}$ & $35.33 \mathrm{~b}$ & 1,631 & $\mathrm{c}$ & $2,174 \mathrm{c}$ & $25: 56$ & $\mathrm{a}$ & $25: 08$ & 0 \\
\hline BRS Valente ${ }^{1}$ & $87.67 \mathrm{a}$ & $86.33 \mathrm{a}$ & $29.52 \mathrm{a}$ & $31.19 \mathrm{~b}$ & 1,919 & $\mathrm{c}$ & $2,573 \mathrm{c}$ & $23: 14$ & $\mathrm{~b}$ & $23: 16$ & $\mathrm{c}$ \\
\hline Guapo Brilhante ${ }^{1}$ & $73.33 \mathrm{~b}$ & $73.00 \mathrm{~b}$ & $26.39 \mathrm{~b}$ & $29.81 \mathrm{c}$ & 2,446 & b & $2,876 \mathrm{~b}$ & $22: 37$ & $\mathrm{~b}$ & $21: 14$ & c \\
\hline Mean land c & 81.56 & 77.07 & 27.60 & 31.48 & 1,507 & & 1,821 & $24: 02$ & & $24: 35$ & \\
\hline Mean control cultivars & 81.58 & 82.41 & 31.53 & 32.15 & 2,112 & & 2,542 & $24: 17$ & & $23: 10$ & \\
\hline
\end{tabular}

* Averages not followed by the same letter within a column differ according to the Scott-Knott test ( $\mathrm{p}=0.05)$.

${ }^{1}$ Control cultivars, developed through research.

The values obtained for grain yield ranged from $438 \mathrm{~kg} \mathrm{ha}^{-1}$ (Banana, Alegrete) to $3,746 \mathrm{~kg} \mathrm{ha}^{-1}$ (Preto Miúdo, Santa Maria) (Table 4). A similar result for the range in the variation of grain yield has been reported in experiments evaluating the agronomic performance of common bean land cultivars (BONETT et al., 2006; ELIAS et al., 2007; RIBEIRO et al., 2008a; ZILIO et al., 2011, 2013). The land cultivars Preto Miúdo and Cavalo Rajado had a higher grain yield than all of the control cultivars evaluated in Alegrete; and these cultivars showed similar or higher grain yield than control cultivars in Santa Maria. Thus, the land cultivars
Preto Miúdo and Cavalo Rajado are promising for selection and use in crossing blocks due to their high grain yield.

The cooking time of a common bean cultivar is decisive for consumer acceptance, and this underscores the importance of its evaluation in bean breeding programs. Among the land cultivars evaluated, only Carioca Santa Maria, Grosso Santa Maria, and Grosso Ibarama grown in Alegrete had cooking times higher than those observed for the control cultivars (Table 4). However, all common bean cultivars evaluated cooked in less than $30 \mathrm{~min}$. According to Rodrigues et al. (2005), $30 \mathrm{~min}$ is 
considered an adequate cooking time for common bean. Moreover, the range in variation observed for the cooking times of the common bean land cultivars, i.e., $18 \mathrm{~min} 23 \mathrm{~s}$ (Banana, Alegrete) to 29 min 53 s (Carioca Santa Maria, Santa Maria), was similar to the values obtained for common bean lines and cultivars by Ribeiro et al. (2013a, 2013b, 2014a). This could indicate that the preservation and development of common bean cultivars in smallholder agriculture have been conducted not only for grain yield or grain type, but also for a reduced cooking time.

With regard to the concentrations of calcium, iron, zinc, and copper in grains (Table 5), none of the common bean land cultivars exceeded the control cultivars. This was expected, as the nutritional composition has not been considered in the preservation of genetic resources in smallholder agriculture or research. However, the minerals concentration observed in the control cultivars Pérola, BRS Valente and Guapo Brilhante was similar to the values obtained for the land cultivars Carioca Santa Maria, Palha Roxa, Preto Miúdo, Carioca Vermelho, and Perdiz for calcium; Banana, Palha Roxa, Carioca Vermelho, and Perdiz for iron; Carioca Santa Maria, Azulão, Banana, Palha Roxa, Amendoim, Amendoim Rio Pardo, Cavalo, Rajado Vermelho, Carioca Vermelho, Perdi, and Tubiano for zinc; and Carioca Santa Maria, Azulão, Banana, Palha Roxa, Cavalo, Cavalo Rajado, Cavalo Rio Pardo, Grosso Santa Maria, Carioca Vermelho and Perdiz for copper.

For the land cultivars that stood out with regard to the calcium concentration in grains, the values obtained, i.e., 2.48 to $3.00 \mathrm{~g} \mathrm{~kg}^{-1}$ dry mass (DM), were considered high according to the classification proposed for common bean grains by Ribeiro et al. (2013a). These values are higher than those reported previously for common bean lines and cultivars in the literature (JOST et al., 2010; RIBEIRO et al., 2013a, 2013b, 2014b) and for common bean land cultivars evaluated in Santa Catarina (PEREIRA et al., 2011). Thus, with respect to the calcium concentration was possible to select cultivars for use in crosses to obtain biofortified common bean cultivars.

However, the common bean land cultivars that had the highest iron concentration, which ranged from 45.39 to $49.29 \mathrm{mg} \mathrm{kg}^{-1} \mathrm{DM}$, were classified as having a low iron concentration according to Ribeiro et al. (2013a). The iron concentrations measured in the common bean land cultivars in the current study were lower than previously reported values (MESQUITA et al., 2007; PEREIRA et al., 2011; RIBEIRO et al., 2013a, 2013b, 2014b; SILVA et al., 2012).

The zinc concentrations in the cultivars ranged from 48.13 to $58.75 \mathrm{mg} \mathrm{kg}^{-1} \mathrm{DM}$ (Table 5). These values were higher than those measured in common bean grains from different commercial classes (RIBEIRO et al., 2008b, 2014b) and are among the highest values observed to certain lines and cultivars of according by Mesquita et al. (2007) and Silva et al. (2012). The copper concentrations in the cultivars varied from 10.86 to $13.13 \mathrm{mg} \mathrm{kg}^{-1}$ DM. These values are higher than those reported previously for common bean lines and cultivars grown in the Rio Grande do Sul state (RIBEIRO et al., 2008b, 2014b) and lower than the values measured in the Minas Gerais state (MESQUITA et al., 2007; SILVA et al., 2012).

A positive correlation with a moderate magnitude was observed between the calcium and iron $(r=0.597)$, iron and zinc $(r=0.570)$, and zinc and copper $(r=0.548)$ concentrations (Table 6). Estimates of similar magnitudes were obtained by Silva et al. (2012) in a study of correlations between the minerals iron-zinc and zinc-copper in 100 common bean lines. A positive association between two minerals enables an increase in their concentration in combined form. Thus, an increase in the iron concentration in grains could be effective for increasing the calcium and zinc concentrations, and with an increase in zinc, the iron and copper concentrations could be increased in common bean grains. The other traits had low or non-significant correlation estimates, indicating that they are not favorable for indirect selection. 
Table 5. Averages* of land and control common bean cultivars for concentrations of calcium, iron, zinc, and copper in grains and the $\bar{Z}$ index, evaluated in Alegrete and Santa Maria, RS, in the 2012/2013 season.

\begin{tabular}{|c|c|c|c|c|c|}
\hline Cultivar & $\begin{array}{c}\text { Calcium } \\
\left(\mathrm{g} \mathrm{kg}^{-1} \mathrm{DM}\right)\end{array}$ & $\begin{array}{c}\text { Iron } \\
\left(\mathrm{mg} \mathrm{kg}^{-1} \mathrm{DM}\right)\end{array}$ & $\begin{array}{c}\text { Zinc } \\
\left(\mathrm{mg} \mathrm{kg}^{-1} \mathrm{DM}\right)\end{array}$ & $\begin{array}{c}\text { Copper } \\
\left(\mathrm{mg} \mathrm{kg}^{-1}-\mathrm{DM}\right)\end{array}$ & $\bar{Z}$ Index \\
\hline Carioca Santa Maria & $2.91 \mathrm{a}$ & $42.00 \mathrm{~b}$ & $55.01 \mathrm{a}$ & $11.89 \mathrm{a}$ & $3.70 \mathrm{a}$ \\
\hline Azulão & $1.91 \mathrm{~b}$ & $42.50 \mathrm{~b}$ & $51.87 \mathrm{a}$ & $12.10 \mathrm{a}$ & $2.79 \mathrm{~b}$ \\
\hline Banana & $1.31 \mathrm{c}$ & $45.60 \mathrm{a}$ & $58.75 \mathrm{a}$ & $11.60 \mathrm{a}$ & $2.84 \mathrm{~b}$ \\
\hline Guabiju & $1.62 \mathrm{~b}$ & $30.30 \mathrm{c}$ & $43.05 \mathrm{~b}$ & $10.18 \mathrm{~b}$ & $2.58 \mathrm{c}$ \\
\hline Palha Roxa & $2.67 \mathrm{a}$ & $45.45 \mathrm{a}$ & $50.82 \mathrm{a}$ & $11.55 \mathrm{a}$ & $3.30 \mathrm{a}$ \\
\hline Preto Miúdo & $2.48 \mathrm{a}$ & $40.17 \mathrm{~b}$ & $46.49 \mathrm{~b}$ & $10.33 \mathrm{~b}$ & $3.66 \mathrm{a}$ \\
\hline Amendoim & $1.06 \mathrm{c}$ & $35.36 \mathrm{c}$ & $49.41 \mathrm{a}$ & $9.42 \mathrm{c}$ & $2.72 \mathrm{~b}$ \\
\hline Amendoim Rio Pardo & $0.98 \mathrm{c}$ & $40.33 \mathrm{~b}$ & $51.07 \mathrm{a}$ & $10.24 \mathrm{~b}$ & $2.95 \mathrm{~b}$ \\
\hline Cavalo & $1.07 \mathrm{c}$ & $33.09 \mathrm{c}$ & $48.13 \mathrm{a}$ & $11.13 \mathrm{a}$ & $2.23 \mathrm{c}$ \\
\hline Cavalo Rajado & $1.27 \mathrm{c}$ & $30.69 \mathrm{c}$ & $40.60 \mathrm{~b}$ & $11.66 \mathrm{a}$ & $2.39 \mathrm{c}$ \\
\hline Cavalo Rio Pardo & $1.62 \mathrm{~b}$ & $34.30 \mathrm{c}$ & $44.63 \mathrm{~b}$ & $13.13 \mathrm{a}$ & $2.53 \mathrm{c}$ \\
\hline Rajado Vermelho & $1.63 \mathrm{~b}$ & $37.21 \mathrm{c}$ & $52.21 \mathrm{a}$ & $10.30 \mathrm{~b}$ & $2.97 \mathrm{~b}$ \\
\hline Grosso Santa Maria & $1.41 \mathrm{c}$ & $28.12 \mathrm{c}$ & $45.63 \mathrm{~b}$ & $10.86 \mathrm{a}$ & $2.54 \mathrm{c}$ \\
\hline Grosso Ibarama & $1.26 \mathrm{c}$ & $32.94 \mathrm{c}$ & $42.28 \mathrm{~b}$ & $8.59 \mathrm{c}$ & $2.78 \mathrm{~b}$ \\
\hline Mourinho & $2.07 \mathrm{~b}$ & $40.83 \mathrm{~b}$ & $42.15 \mathrm{~b}$ & $9.30 \mathrm{c}$ & $3.08 \mathrm{a}$ \\
\hline Mourinho Marrom & $1.98 \mathrm{~b}$ & $39.07 \mathrm{~b}$ & $37.01 \mathrm{~b}$ & $9.09 \mathrm{c}$ & $2.85 \mathrm{~b}$ \\
\hline Carioca Vermelho & $2.25 \mathrm{a}$ & $47.59 \mathrm{a}$ & $54.89 \mathrm{a}$ & $10.98 \mathrm{a}$ & $3.44 \mathrm{a}$ \\
\hline Perdiz & $3.00 \mathrm{a}$ & $47.86 \mathrm{a}$ & $53.14 \mathrm{a}$ & $12.19 \mathrm{a}$ & $3.53 \mathrm{a}$ \\
\hline Tubiano & $1.61 \mathrm{~b}$ & $36.55 \mathrm{c}$ & $51.78 \mathrm{a}$ & $7.98 \mathrm{c}$ & $2.49 \mathrm{c}$ \\
\hline Carioca $^{1}$ & $2.04 \mathrm{~b}$ & $39.43 \mathrm{~b}$ & $42.61 \mathrm{~b}$ & $9.85 \mathrm{~b}$ & $3.05 \mathrm{a}$ \\
\hline Pérola $^{1}$ & $2.88 \mathrm{a}$ & $46.69 \mathrm{a}$ & $53.48 \mathrm{a}$ & $11.06 \mathrm{a}$ & $3.34 \mathrm{a}$ \\
\hline BRS Valente $^{1}$ & $2.65 \mathrm{a}$ & $45.39 \mathrm{a}$ & $53.21 \mathrm{a}$ & $11.29 \mathrm{a}$ & $3.43 \mathrm{a}$ \\
\hline Guapo Brilhante ${ }^{1}$ & $2.87 \mathrm{a}$ & $49.29 \mathrm{a}$ & $51.57 \mathrm{a}$ & $11.11 \mathrm{a}$ & $3.31 \mathrm{a}$ \\
\hline Mean land cultivars & 1.73 & 38.42 & 48.36 & 10.66 & 2.91 \\
\hline Mean control cultivars & 2.61 & 45.20 & 50.22 & 10.83 & 3.28 \\
\hline
\end{tabular}

*Averages not followed by the same letter within a column differ according to the Scott-Knott test $(p=0.05)$.

${ }^{1}$ Control cultivars, developed through research.

When considering the simultaneous selection of several traits, it is not always possible to identify cultivars that contain all traits that are favorable for selection. The land cultivars Palha Roxa, Carioca Vermelho, and Perdiz stood out with respect to the concentrations of calcium, iron, zinc, and copper in grains (Table 5). However, these cultivars had an intermediate cycle and low grain yield (Table 4). Thus, the use of selection indices becomes necessary to identify common bean cultivars with high agronomic performance and nutritional quality. The $\bar{Z}$ index has recently been used in common bean breeding programs for selecting superior lines for several traits simultaneously (SILVA et al., 2012; RIBEIRO et al., 2013a, 2013b, 2014b).

The Carioca Santa Maria cultivar had the highest $\bar{Z}$ index average for the traits evaluated, followed by the cultivars Preto Miúdo, Perdiz, Carioca
Vermelho, BRS Valente, Pérola, Guapo Brilhante, Palha Roxa, and Mourinho (Figure 1). For Carioca Santa Maria cultivar, the highest $\bar{Z}$ indices were observed for the concentrations of calcium, iron, zinc, and copper in grains. However, the $\bar{Z}$ indices obtained for the insertion of the first pod, grain yield, and cooking time were not favorable for selection. The Guapo Brilhante cultivar had high $\bar{Z}$ indices for grain yield and the concentrations of calcium, iron, zinc, and copper in grains, and low indices for the cycle and cooking time. As the cultivars Carioca Santa Maria and Guapo Brilhante had complementary traits, crossing these cultivars is recommended for breeding programs. Selection of the recombinants obtained could result in a new common bean cultivar with an early cycle, a higher insertion of the first pod, a high grain yield, reduced cooking time, and high concentrations of the minerals calcium, iron, zinc, and copper in grains. 
Figure 1. Representation of the $\bar{Z}$ index for number of days from emergence to maturation (cycle), insertion of the first pod (first pod), grain yield (yield), cooking time (time), and concentrations of calcium (Ca), iron (Fe), zinc ( $\mathrm{Zn}$ ), and copper $(\mathrm{Cu})$ in grains of nine common bean cultivars that had highest average $\bar{Z}$ index estimates.

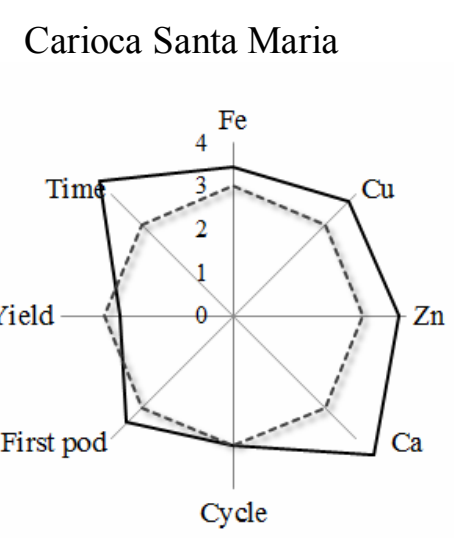

Carioca Vermelho

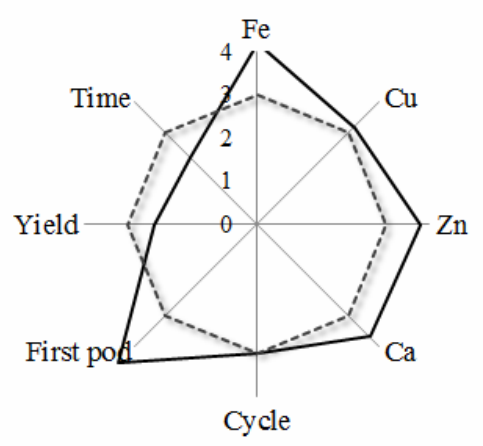

Guapo Brilhante

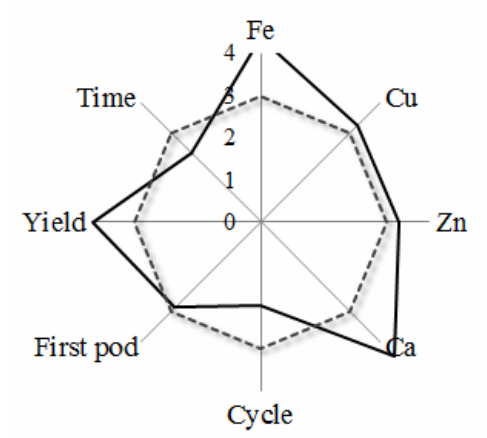

Preto Miúdo

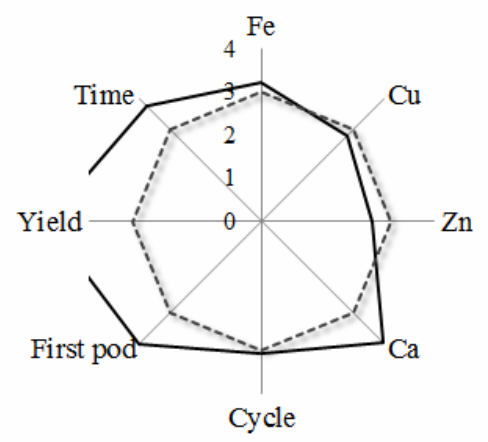

BRS Valente

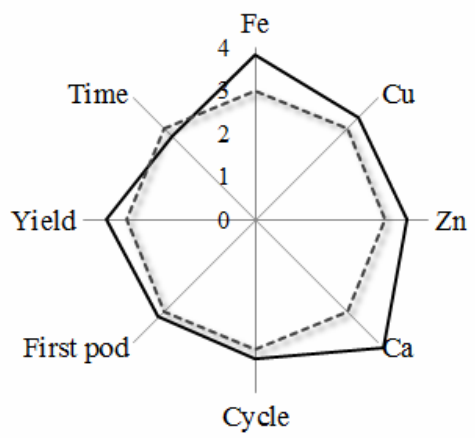

Palha Roxa

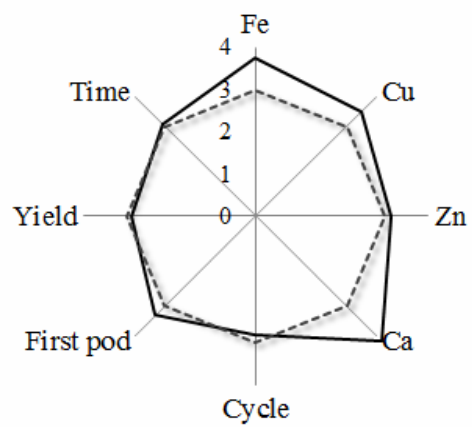

Perdiz

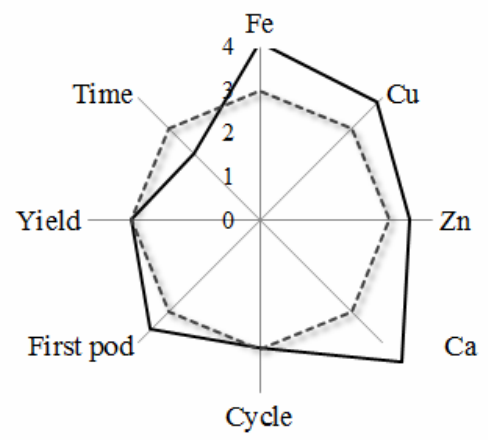

Pérola

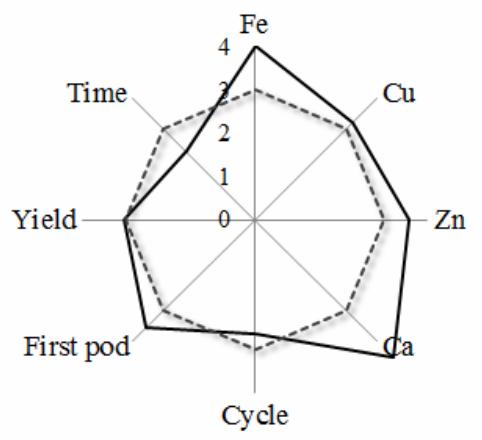

Mourinho

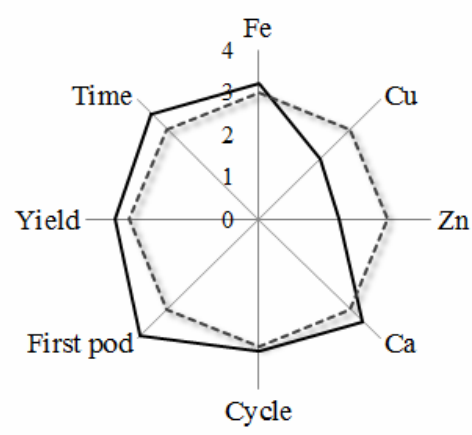

Legend: $=\mathrm{Z}$ index; $----=$ average $=3$ 
Table 6. Pearson correlation coefficients of land and control bean cultivars for the traits grain yield (yield), number of days from emergence to maturation (cycle), insertion of the first pod (first pod), cooking time (cooking), and concentrations of calcium, iron, zinc, and copper in grains, evaluated in Alegrete and Santa Maria, RS, in the 2012/2013 season.

\begin{tabular}{llcccccc}
\hline & Cycle & First pod & Cooking & Calcium & Iron & Zinc & Copper \\
\hline Yield & $-0.218 *$ & 0.135 & 0.098 & $0.341 *$ & 0,097 & $-0.226 *$ & 0.150 \\
Cycle & & $0.481 *$ & 0.112 & 0.110 & $0.217 *$ & $0.173 *$ & $-0.307 *$ \\
First pod & & & $0.234 *$ & $0.332 *$ & $0.259 *$ & 0.004 & $-0.305 *$ \\
Cooking & & & & 0.021 & -0.136 & -0.116 & -0.161 \\
Calcium & & & & & $0.597 *$ & $0.274 *$ & $0.256 *$ \\
Iron & & & & & & $0.570 *$ & $0.344 *$ \\
Zinc & & & & & & $0.548 *$ \\
\hline
\end{tabular}

* Significant according to the $t$ test $(\mathrm{p}<0.05)$.

\section{Conclusions}

The common bean land cultivars differ with respect to the cycle, insertion of the first pod, grain yield, cooking time, and concentrations of calcium, iron, zinc, and copper in grains.

Indirectly selecting for high iron or zinc concentrations in grains could be effective for obtaining common bean cultivars with a higher nutritional quality.

The Guapo Brilhante cultivar has high $\bar{Z}$ index values for grain yield and the concentrations of calcium, iron, zinc, and copper in grains, but lower values for the cycle and cooking time. Consequently, this cultivar could be selected for a breeding program for use in directed hybridizations.

\section{Acknowledgements}

We thank the National Council of Technological and Scientific Development (CNPq) and the Coordination for the Improvement of Higher Education Personnel (CAPES) and the for the grants awarded.

\section{References}

ASSOCIAÇÃO BRASILEIRA DE SEMENTES E MUDAS - ABRASEM. Estatísticas. Brasília: ABRASEM, 2015. Disponível em: <http://www. abrasem.com.br/site/estatisticas/\#>. Acesso em: 17 nov. 2015.

BONETT, L. P.; GONÇALVES-VIDIGAL， M. C.; SCHUELTER, A. R.; VIDIGAL FILHO, P. S.; GONELA, A.; LACANALLO, G. F. Divergência genética em germoplasma de feijoeiro comum coletado no estado do Paraná, Brasil. Semina: Ciências Agrárias, Londrina, v. 27, n. 4, p. 547-560, 2006.

COELHO, C. M. M.; ZILIO, M.; SOUZA, C. A.; GUIDOLIN, A. F.; MIQUELLUTI, D. J. Características morfo-agronômicas de cultivares crioulas de feijão comum em dois anos de cultivo. Semina: Ciências Agrárias, Londrina, v. 31, n. 1, p. 1177-1186, 2010.

COMISSÃO TÉCNICA SUL-BRASILEIRA DE FEIJÃO - CTSBF. Informações técnicas para o cultivo de feijão na região Sul brasileira. 2. ed. Florianópolis: Epagri, 2012. 157 p.

CRUZ, C. D. GENES - a software package for analysis in experimental statistics and quantitative genetics. Acta Scientiarum Agronomy, Maringá, v. 35, n. 3, p. 271-276, 2013.

ELIAS, H. T.; GONÇALVES-VIDIGAL， M. C.; GONELA, A.; VOGT, G. A. Variabilidade genética em germoplasma tradicional de feijão-preto em Santa Catarina. Pesquisa Agropecuária Brasileira, Brasília, v. 42, n. 10, p. 1443-1449, 2007.

FRANKEL, R.; GALUN, E. Pollination mechanisms, reproduction and plant breeding. New York: SpringerVerlag, 1977. $281 \mathrm{p}$.

JOST, E.; RIBEIRO, N. D.; CARGNELUTTI FILHO, A.; ANTUNES, I. F. Composição de macrominerais em cultivares de feijão e aplicações para o melhoramento genético. Pesquisa Agropecuária Gaúcha, Porto Alegre, v. 16, n. 1, p. 31-38, 2010. 
MENDES, F. F.; RAMALHO, M. A. P.; ABREU, A. de F. B. Índice de seleção para escolha de populações segregantes de feijoeiro comum. Pesquisa Agropecuária Brasileira, Brasília, v. 44, n. 10, p. 1312-1318, 2009.

MESQUiTA, F. R.; CORREAA, A. D.; ABREU, C. M. P. de; LIMA, R. A. Z.; ABREU, A. de F. B. Linhagens de feijão (Phaseolus vulgaris L.): composição química e digestibilidade proteica. Ciência e Agrotecnologia, Lavras, v. 31, n. 4, p. 1114-1121, 2007.

MINISTÉRIO DA AGRICULTURA, PECUÁRIA E ABASTECIMENTO - MAPA. Consulta de ingrediente ativo. Brasília: MAPA, 2015. Disponível em: $<$ http:// agrofit.agricultura.gov.br/agrofit_cons/principal_agrofit_ cons>. Acesso em: 18 nov. 2015.

MIYAZAWA, M.; PAVAN, M. A.; MURAOKA, T.; CARMO, C. A. F. S.; MELLO, W. J. Análises químicas de tecido vegetal. In: SILVA, F. C. Manual de análises químicas de solos, plantas e fertilizantes. Brasília: Embrapa Comunicação para Transferência de Tecnologia, 1999. p. 171-223.

PEREIRA, T.; COELHO, C. M. M.; SANTOS, J. C. P. dos; BOGO, A.; MIQUELLUTI, D. J. Diversidade no teor de nutrientes em grãos de feijão crioulo no Estado de Santa Catarina. Acta Scientiarum Agronomy, Maringá, v. 33, n. 3, p. 477-485, 2011.

RIBEIRO, N. D.; ANTUNES, I. F.; POERSCH, N. L.; ROSA, S. S.; TEIXEIRA, M. G.; GOMES, A. L. da S. Potencial de uso agrícola e nutricional de cultivares crioulas de feijão. Ciência Rural, Santa Maria, v. 38, n. 3, p. 628-634, 2008a.

RIBEIRO, N. D.; CARGNELUTTI FILHO, A.; POERSCH, N. L.; ROSA, S. S. Padronização de metodologia para avaliação do tempo de cozimento dos grãos de feijão. Bragantia, Campinas, v. 66, n. 2, p. 335348, 2007.

RIBEIRO, N. D.; DOMINGUES, L. da S.; GRUHN, E. M.; ZEMOLIN, A. E. M.; RODRIGUES, J. A. Desempenho agronômico e qualidade de cozimento de linhagens de feijão do grupo especiais. Ciência Agronômica, Fortaleza, v. 45, n. 1, p. 92-100, 2014a.

RIBEIRO, N. D.; DOMINGUES, L. da S.; ZEMOLIN, A. E. M.; POSSOBOM, M. T. D. F. Selection of common bean lines with high agronomic performance and high calcium and iron concentrations. Pesquisa Agropecuária Brasileira, Brasília, v. 48, n. 10, p. 1368-1375, $2013 a$.
RIBEIRO, N. D.; JOST, E.; CERUTTI, T.; MAZIERO, S. M.; POERSCH, N. L. Composição de microminerais em cultivares de feijão e aplicações para o melhoramento genético. Bragantia, Campinas, v. 67, n. 2, p. 267-273, 2008 b.

RIBEIRO, N. D.; MANBRIN, R. B.; STORCK, L.; PRIGOL, M.; NOGUEIRA, C. W. Combined selection for grain yield, cooking quality and minerals in the common bean. Revista Ciência Agronômica, Fortaleza, v. 44, n. 4, p. 869-877, 2013 b.

RIBEIRO, N. D.; RODRIGUES, J. de A.; PRIGOL, M.; NOGUEIRA, C. W.; STORCK, L.; GRUHN, E. M. Evaluation of special grains bean lines for grain yield, cooking time and mineral concentration. Crop Breeding and Applied Biotechnology, Viçosa, MG, v. 14, n. 1, p. 15-22, 2014b.

RODRIGUES, J. de A.; RIBEIRO, N. D.; LONDERO, P. M. G.; CARGNELUTTI FILHO, A.; GARCIA, D. C. Correlação entre absorção de água e tempo de cozimento em cultivares de feijão. Ciência Rural, Santa Maria, v. 35 , n. 1, p. 209-214, 2005.

SCOTT, A.; KNOTT, M. Cluster-analysis method for grouping means in analysis of variance. Biometrics, Washington D.C., v. 30, n. 3, p. 507-512, 1974.

SILVA, C. A.; ABREU, A. de F. B.; RAMALHO, M. A. P.; MAIA, L. G. S. Chemical composition as related to seed color of common bean. Crop Breeding and Applied Biotechnology, Viçosa, MG, v. 12, n. 1, p. 132-137, 2012.

ZILIO, M.; COELHO, C. M. M.; SOUZA, C. A.; SANTOS, J. C. P.; MIQUELLUTI, D. J. Contribuição dos componentes de rendimento na produtividade de genótipos crioulos de feijão (Phaseolus vulgaris L.). Revista Ciência Agronômica, Fortaleza, v. 42, n. 2, p. 429-438, 2011.

ZILIO, M.; SOUZA, C. A.; COELHO, C. M. M.; MIQUELLUTI, D. J.; MICHELS, A. F. Cycle, canopy architecture and yield of common bean genotypes (Phaseolus vulgaris) in Santa Catarina State. Acta Scientiarum Agronomy, Maringá, v. 35, n. 1, p. 21-30, 2013.

ZIMMERMANN, M. J. de O.; TEIXEIRA, M. G. Origem e evolução. In: ARAÚJO, R. S.; RAVA, C. A.; STONE, L. F.; ZIMMERMANN, M. J. de O. Cultura do feijoeiro comum no Brasil. Piracicaba: Potafós, 1996. p. 57-70. 